Open Access

\title{
Royal religious beneficence in pre-modern India: social and political implications
}

Nalini Rao

\author{
Correspondence: nrao@soka.edu \\ Diacritical marks have been used \\ only for Sanskrit and Kannada \\ words and texts and not for names \\ of kings and places. \\ Soka University of America, 1 \\ University Drive, Aliso Viejo, Ca \\ 92656, USA
}

\begin{abstract}
The aim of the paper is to understand the role of royal charitable gifts or dāna in the background of Hindu religious ideology of dharma, temple urbanism and political power in pre-modern South India. It examines the phenomena of large royal charities between the $14^{\text {th }}$ and $16^{\text {th }}$ centuries ACE under the Vijayanagar kings in the capital city of Vijayanagar (modern Hampi). The temple cities in the capital city owed their wealth largely to royal benefaction which was a continuation of Hindu religious tradition from ancient times. Drawing on iconographical, inscriptional and literary sources the paper explores the symbolic and religious values of benevolence which can shed light on temple patronage and Vijayanagar kingship. With the help of artistic and historical evidences, it provides a glimpse into the workings of mahädānas (large gifts) and relationship between the palace, bazaar and the temple. Through the mechanism of ritual gifting as an intrinsic aspect of 'dharmic' kingship, the Vijayanagar kings were able to maintain a complex set of interrelationships and networks of power. The institutionalization of traditional system of gifting, represented in official architecture and visual imagery reflects the dyanamism of a complex system of royal gifting that played an important role in the maintenance of religious and political power.
\end{abstract}

Keywords: dāna, mahādānas, Vijayangar, Gift giving, Temple cities, Royal gifts, Temple urbanism, Hindu sculpture, rājadharma

\section{Background}

The ancient Indian practice of religious gifting or dāna has played a key role in the patronage of Indian temple art and architecture. Between c. 1336 and c. 1556 ACE, South India was ruled by the Vijayanagar empire,with its capital city of Vijayanagar (or modern Hampi). Ultimately, Vijayangar was ransacked by the combined Moslem armies of Ahmadnagar, Golcunda and Bijapur in 1565 A.C.E. The city of Vijayanagara (or modern Hampi) occupied an extensive area on the southern banks of the River Tungabhadra in the Hospet Taluk of Bellary District in the State of Karnataka. ${ }^{1}$ It was surrounded by seven man-made walls of fortification, the outer walls of which covered a large area, approximately $350 \mathrm{sq} . \mathrm{kms}^{2}{ }^{2}$ The ruins of Hampi still contain a built environment that encompass large temple cities, palaces, bazaars, walls, gateways, towers, aqueducts, platforms, tanks that reflect the power and prestige of its rulers. Some of the structures are articulated with sculptures and reliefs that help us to understand the role of art in expressing and defining the concept of liberal kingship and nature of

\section{Springer}

(c) 2016 The Author(s). Open Access This article is distributed under the terms of the Creative Commons Attribution 4.0 International License (http://creativecommons.org/licenses/by/4.0/), which permits unrestricted use, distribution, and reproduction in any medium, provided you give appropriate credit to the original author(s) and the source, provide a link to the Creative Commons license, and indicate if changes were made. 
royal authority. The Vijayanagar kings gifted large sums of money and gold to the temples which provided for temple services and helped local merchants. In addition, tem-

ples could function as landholders, employers, promoter of industries, regulators of trade and of the guild system. Its economy was tied to the charities of the king and sometimes acted as his agent. Through the temple, the Vijayanagar king exercised authority on the market, reaffirming his pre- eminent position, as protector and provider. Such a gift economy was reflected in iconographical and artistic imagery, which reveal the complex economic system that sustained temple urbanism and balance of power between the religious, political and economic institutions. The visual arts in the capital city of Vijayanagara (Hampi) and the available historical evidences throw an interesting light on the transactional relationship between the donor and the ruled, authority and reciprocity within a system of network alliances.

\section{Method}

The paper utilizes art-historical method of enquiry on two levels: the particular and the general. The former includes the identification and visual analysis of images connected with kingship in the form of architecture and sculptural reliefs. On the contextual level, it involves an understanding of the visual in the context of literary sources: inscriptions, ancient sacred texts, contemporary narratives and accounts of foreign travelers. The paper is a multidisciplinary analysis of dāna as practiced by Vijayanagar royalty through an examination of the form and content of sculptural articulations in the context of historical evidences.

\section{Introduction}

Religious gifting as an individual and social practice has been embedded in ancient Indian religious traditions of Hinduism, Buddhism and Jainism. ${ }^{3}$ Gift-giving or dāna has been an integral part of Hindu dharma (religious ethics) particularly in relation to rājadharma (royal obligation) that had immense social and political implications in the empire of Vijayanagar, that ruled South India between c. 1336 and 1565 ACE. ${ }^{4}$ The theory of gifting has been studied exhaustively by eminent scholars such as Marcel Mauss (1966) who emphasized the force of obligatory return and exchange and its creation of a set of relations. ${ }^{5}$ Mariam Helm who based her research upon dāna in South Asia, concludes that it had an ethical basis ${ }^{3}$ while Diana Eck (2013) examines dāna as an intricate aspect of dharma with its ethical and philosophical foundations. ${ }^{6}$ In regard to the definition of dāna, the concept has been discussed elaborately in ancient Indian Hindu sacred texts including the Dānastutis in the RgVeda, Viśnudharmottara Purana (1912) and the Manusmriti; all the texts unequivocally agree about its importance for the sake of gaining punya (merit), pleasing the gods, obtainment of heaven and assurance of safety and protection. ${ }^{7}$ The Viśnusmriti and the Manusmriti clearly mention the particular benefits accrued by the giving of specific gifts (such as cows, gold, mountain, land, lamps, crops, knowledge, food, clothes, bed, shoes, fan etc.). ${ }^{8}$ They explicitly state the importance of its acceptance, the charity to be directed towards worthy persons, the auspicious time, the ritual procedure of gift-giving and the spirit with which it should be done. Dāna in religious texts, was considered obligatory, a great duty and was a practice of dharma. At the feet of dharma lay the four concepts: knowledge, gift, penance and truth. ${ }^{9}$ 


\section{Practice of royal gifting}

Dāna was considered to be a part of dharma for both householders and kings. The latter enacted mahädānas or great gifts which were described in great detail in the Puranas (quasi historical texts). In the Matsya Purana, the gifts by kings were known as mahädānani. ${ }^{10}$ Once the puranic tradition and importance accorded to royal gifting had become part of räjadharma, it continued as a living belief and was practiced in ancient and medieval periods by Hindu kings. By the Gupta period it was established as a part of royal duty or rājadharma which entailed gifting to brähmaṇas and religious institutions, particularly Hindu temples. Harsa is said to have gifted a town along with its land-tax for the success of his parents. Every fifth year he used to hold modsamahapariśad at Prayag and gave his treasury in charity.

One can trace the history of royal gifts in South India to the Sangama period (c.300 BCE.) that continued under the Cholas in Tiruchirapalli, Pandyas in Madurai and Cheras in Kerala. The Pallavas (c. 500 ACE - c. 900 ACE) in Tondaimandalam proclaimed themselves as protectors of dharma and donated gifts lavishly to temples and brāhmanas at royal rituals from booty obtained from war thereby tying temple arts to political power. The Rashtrakuta kings performed large gifting ceremonies as mahädānas. ${ }^{11}$ In fact, gifting as an institutional practice of kingship gained importance when sacrificial kingship was replaced by the notion of dāna. Great gifts that were earlier considered as ritual dues and tied to the performances of the royal rājasuya and aśvamedha sacrifices during the consecration of kings now gained individual importance. According to Ronald Inden (1978), great gifts or mahädānas were performed as a replacement of the srauta sacrifices by the Rastrakuta king, Dantidurga, around c. 757 ACE. ${ }^{12}$ The continued importance of dāna can be found in sacred texts such as Dharmasastra Nibandha by Lakshimdhara which was popular in South India and the ideology of dāna was clearly stated in Caturvarga Cintamani. ${ }^{13}$

With the rise of the Cholas between c. 849 ACE. and c.1279 ACE., around the capital city of Tanjore, kings functioned as patrons of monumental temples which became the nucleus for the growth of South Indian urbanism. Temples from around $8^{\text {th }} \mathrm{C}$. ACE. onwards, were not merely religious places of worship, but were educational and economic institutions playing a key role in the process of urbanization and in the development of markets. ${ }^{14}$ Largely patronized by kings and nobility, temple-cities or puras grew to be key institutions in the structure of power, largely due to large gifts or mahādānas. ${ }^{15}$ About 10,000 stone inscriptions engraved on the walls, pillars and even pavements of temples constitute a vast scholarly resource for a socio-religious understanding of gifting. They continued to be the nucleus for the growth of a vibrant economic system which functioned within a broader built environment in $14^{\text {th }} \mathrm{C}$. ACE. ${ }^{16}$ By the time of the Cholas, the great gift ceremony became a "principal ritual modality of kingly beneficence as well as a sign of over-lordship and independence". ${ }^{17}$ By $14^{\text {th }} \mathrm{C}$ ACE., liberal gifts to temples and brāhmanas had become an established mode of räjadharma. During the Vijayanagara period (1336-1565 ACE) construction of temples was a forceful precedent for the kings' establishment of a powerful kingdom.

\section{Temple urbanism at Vijayanagar}

The temple economy at Vijayanagar and in many temple cities in the empire, was tied to the charities of the king. Its dynamic workings on temple economics and political 
power can be understood with the help of royal images within the built environment of temple cities in the capital city of Vijayangar. Dividing the city on the basis of natural and man-made features, Michell and others distinguish two major zones, the sacred center which is in the northern part of the city, and a royal center, within the innermost fortification, within an urban core. ${ }^{18}$ The sacred center is dominated by four large temple complexes: the Virupaksa, Krisna, Tiruvengalanatha (or Acyuta Raya) and Vitthala temples. These large temple complexes, or cities (puras) were known by the name of the temple; thus there is the Virupaksapura, Krisnapura, Vitthalapura and Tiruvengalanathapura (or Acyutarayapura) The main feature of a pura is the large temple complex with its high enclosure walls and towered gateways, approached by a long chariot street flanked on both sides by shops (angadi), which functioned as a bazaar. ${ }^{19}$ The architectural assemblage of the temple cities of Krisnapura, Vitthalapura, Virupaksapura and Tiruvengalanathapura, were agro-urban creations. These complexes were built from large grants made by kings and nobles. Distinguished by a large enclosure within which were tanks, wells, schools, they were entered through a towered gate and approached by a long colonnade street which functioned as a market or bazaar for the exchange of goods. In these markets along the chariot streets, were sold gold, rubies, pearls, diamonds openly in the bazaars. ${ }^{20}$ In fact, each temple complex was surrounded by an agricultural hinterland, residences, craft industries, markets and water facilities which were strongly tied to local economy. The temples particularly in the sacred center, utilized a variety of food articles, including coconut, rice, turmeric, incense, leaves, flowers, lights, butter, salt, pepper, betel leaves and nut, oil, mustard, sugar, plantain leaves, flowers, lamps, butter, salt, pepper, mustard, pulses, sugar, bananas, firewood, cotton clothing, as well as articles from foreign markets, musk, camphor, saffron for the multiple functions of worship, ritual celebration, teaching and feeding. Indirectly, the demand promoted industries such as cotton, jewelry and stone workers. The important industries that grew around Vijayanagar temple towns were those of artisans, weavers, oil pressers, ceramic vessels, textiles, jewelry, armor, weapons, stone carvers, leather workers, barbers, potters and washers. The temples even constructed the road system for effective transportation of food and distribution of goods around the capital, thereby playing a significant role in the urban landscape in the temple cities or puras in the capital city of Vijayanagar.

As a religious institution, the temple was obliged to perform a large variety of rituals, which had increased substantially. This required the employment of ritual specialists, priests, managers, accountants, watchmen, storekeepers, drummers, singers, conchblowers, parasol- bearers, gardeners, dancing girls, musicians, and brāhmanas to recite mantras or chants. Temple staff was paid either in cash or kind and sometimes with land which could not be sold or mortgaged. Although the temple was a landholder, promoter of industries and employer its administration came under the growing control of royalty which developed its network of temple controls through endowments to brāhmanas who functioned through temples and did not act as independent landlords. ${ }^{21}$ The temple economy at Vijayanagara and in many temple cities in the empire was tied to the charities of the king and sometimes acted as his agent. Temples acted as tax collectors, and taxed the industries and shops located in the market just outside their enclosures at Hampi. They taxed amgadi or shops, magga or weaving looms, pimjanigära or comber of cotton, agasaru or washerman, talavärike or police, hulubamni 
or hay collector, uppinamole or salt pan and crops and even the ferry service across the Tunga river. ${ }^{22}$ Being central to the production and exchange system, it is not surprising to find the temple cities dominating the rathäpathis or market streets at Vijayanagara, the hinterland and villages outside its walls, while the security for all these interlinked organizations was provided by the king. ${ }^{23}$

The Vijayanagar kings of Sangama, Suluva, Tuluva and Aravidu dynasties were responsible for the restoration of innumerable temples, construction of new mandapas, and elaboration of temple organizations in many temple towns and cities. ${ }^{24}$ Innumerable inscriptions in Karnataka, Tamil Nadu and Andhra Pradesh provide substantial evidence of a large variety of gifts, their purpose as well as the occasion. Although all the religious gifts may be considered as devotional in purpose, the gifts had various other functions besides the king achieving spiritual benefit for the worshippers. ${ }^{25}$ Gifts were made for the construction of large and small temples, for worship and maintenance of rituals; they ranged from small articles for ritual worship to large sums of gold and money to tracts of land. Gifts were made on every important occasion, such as the founding of a dynasty, coronation or eclipse, or commemorative of victories or coronations. Two records in the Virupaksa temple refer to the coronation of Krisnadeva Raya and few additions to the temple of Virupaksa to commemorate the event. ${ }^{26}$ The gôpura of the Vitthalaswami temple was built in c. 1513 ACE. by Krisnadeva Raya and his two queens after the capture of Udayagiri and the king is said to have visited Srisailam and Ahobalam, where he made donations and benefited the temples.

\section{Gift-giving scene}

However, the sociological implications of royal gifting may be conjectured by few artistic evidences that throw light on the relation between gift giving, temple patronage and kingship at Vijayanagar. Two unique royal images are found at Vijayanagar which offer a new insight about the function and role of gifting in the history of South Indian art. The two groups of royal images are those of Acyuta Raya (1530-1542 ACE.) and Krisnadeva Raya 1509-1530 ACE. The former is portrayed in a small shrine in the courtyard of the Tiruvengalanatha temple (also called Acyuta Raya temple) in Tiruvengalanathapura (Fig. 1). In the mandapa or portico of the shrine, on each of the four pillars is a portrait of a king facing the entrance and which are highly visible from the courtyard. The identification of the portrait as that of a king can be established with reasonable certainty, through the criteria of lakshanas or iconographical marks of royaltycap, earrings and drapery. More significant is the architectural context as the temple was built by Acyuta Raya; as well as on an idiosyncratic feature, his stout physiognomy. ${ }^{27}$ On the pillar at the back, is a portrait image which depicts a figure wearing an upper and lower garment in a gesture of gifting: with the thumb and first finger joined and the other three extended. On his right side is a young brähmin boy: his head is shaven and he has a small pony tail and his arms are extended as though he is receiving the gift (Fig. 2). From the inscriptional record, we can gather that Acyuta Raya made numerous donations to brähmanas and priests with gifts of gold, village and lands.

There are about nine inscriptional records which praise the gifts of Acyuta Raya who was known for his generosity and magnanimity. Acyuta Raya made numerous donations to temples, brāhmaṇas and poets with gifts of gold, villages and lands. ${ }^{28}$ 


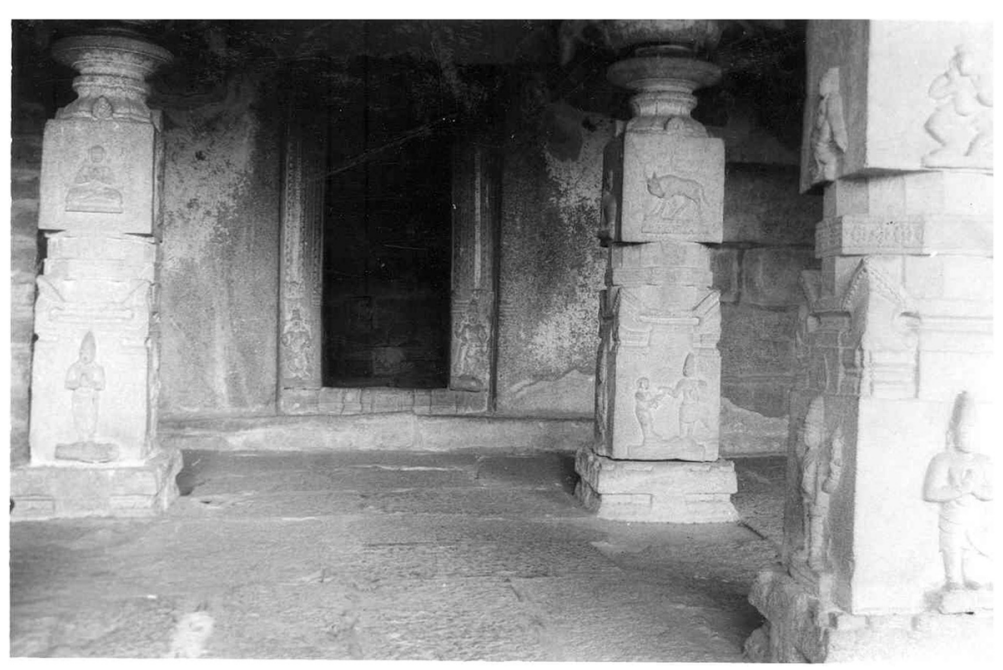

Fig. 1 Porch in Tiruvengalanatha (Acyuta Raya) temple depicting the images of kings on the pillars, Hampi

In fact, the king is said to have visited Kanchipuram in c. 1532 A.C.E. and had himself weighed against gold. Another record of Acyuta Raya is in the Vitthala temple which refers to the gift of the golden mountain suvarnameru c.1533 ACE. ${ }^{29}$ However, it is not certain whether the above mentioned gift giving scene (Fig. 2) depicts a specific gift made by the king or whether it represents a generic scene. Among the nine inscriptions of Acyuta Raya, seven in the Vitthala temple at Vijayanagara praise the king for the gift of pot of gold, annandanidhi in August c.1539 ACE. It is likely that the most likely gift-giving event would be that of ānandanidhi performed in c. 1539 ACE. as Acyuta Raya is said to have performed it several times. The gift of annandanidhi, meaning a pot of gold made to the learned brähmaṇas involved pots made of udambara wood filled with precious stones and coins of gold, silver or copper. It was performed in c. 1533 ACE. and in c. 1539 ACE. when gifts were given to brähmaṇas. However, it is only the anandanidhi gift of c. 1539 ACE that has been mentioned in seven of his nine gift-giving inscriptions at Vijayanagara. It has been mentioned twice in the Krishnaswamy temple, twice in the Acyuta Raya temple (one of these is on the gôpura of the temple), once in the Pattabhirama temple, once in the Cikkahude temple and once in the Vitthala temple. By the gift of c. 1539 ACE Acyuta Raya is said to have made the brähmanas equal to Kubera, the god of wealth and the merit accruing from this ceremony is said to be longevity, perfect health and imperial sovereignty. ${ }^{30}$ As the temple was built and consecrated in c. 1539 ACE. when the particular gift was made, the gift-giving scene on the pillar must have been carved at that time. The fact that the figures are not as well-finished as the other figures in the shrine supports the view that they must have been carved within a short time.

\section{Results and discussion}

It is likely that the gift-giving scene depicts the anandanidhi gift of c. 1539 A.C.E. The reason for making large gifts soon after his accession to the throne might be sought in the list of contenders for the throne. Perhaps, he wished to secure his throne by 


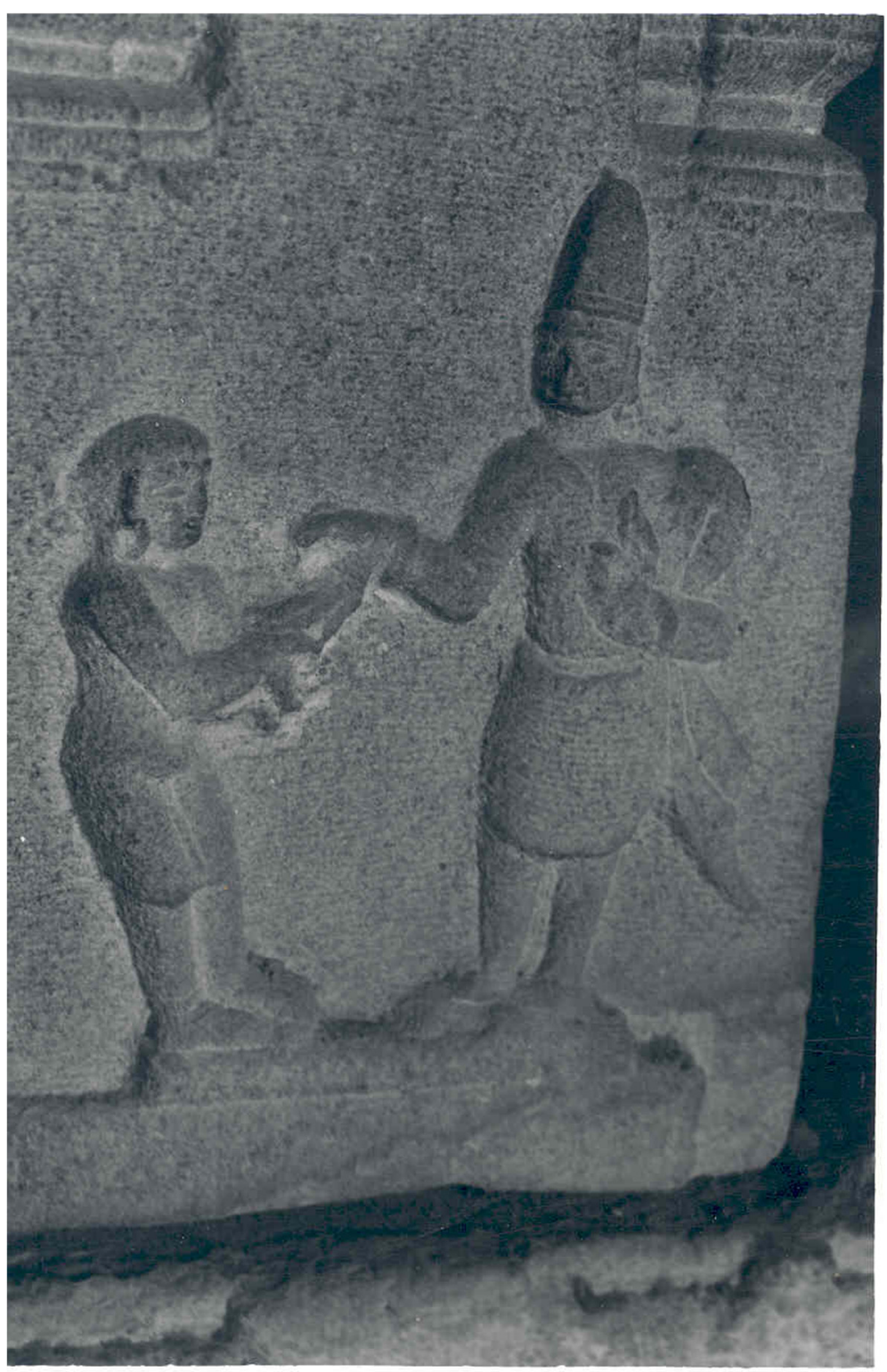

Fig. 2 Acyuta Raya gifting to a brahmin boy

securing the good will of his nobles and chiefs and to strengthen his claim over it as he was not the son and immediate heir of Krisnadevaraya. In fact, the throne had been threatened by Rama Raya, the son-in-law of Krisnadeva Raya. After the demise of Krisnadeva Raya, there was a controversy about accession and Acyuta Raya is said to have been crowned thrice, ${ }^{31}$ first at Tirupati as soon as he heard the news of his brother's death, second at Kalahasti and the third time at the capital. ${ }^{32}$ As the position of the king was uncertain (especially with Rama Raya as the contender to the throne for a long time), it was perhaps appropriate to make a large number of gifts to gain additional popularity and status in order to secure his throne. ${ }^{33}$ Whether the scene depicts a specific event or not, what is obvious is that the portrait was sculpted for 
the specific purpose of showing his liberal nature and enhancing his prestige in the capital and visual imagery substantiated the ideological powers of gift giving.

The second group of portraits is on a unique permanent stone structure in the city of Vijayanagara, called the Balance, locally known as the tulābhāra, located near the Vitthala temple in Vitthalapura (Fig. 3). The structure consists of two pillars that support a central beam. It has provisions to hang a balance which was probably made of metal especially used to make mahādannas. The king was weighed against gold and precious stones which were gifted to all classes of society, brähmanas and temples. On the base of the Balance pillars are depicted the portraits of Krisnadeva Raya and his two queens Chinna Devi and Tirumala Devi which attest that the structure was built by the king after his victory over the Gajapatis of Orissa. The identification is also based upon the degree of iconographical resemblance to the royal (inscribed) portrait images of Krisnadeva Raya and his two wives in the pratima mandapa in the northern entrance of the gateway of the Tirumalai temple at Tirupati. ${ }^{34}$

It might be pertinent to enquire about the small scale of the portraits of both Krisnadevaray on the balance and that of Acyuta Raya. This might have been due to many reasons: one being,that they were in a temple context and the king could not be accorded more importance in the context of the temple, meaning the God in the sanctum. Hence they were placed on pillars, and gateways; while in a secular context, the large royal sculptures found in the archaeological excavations, were probable in a palace context. ${ }^{35}$ The relief portrait of Acyuta Raya appears to be a religious statement made in the context of the temple-god relationship. The king's relief portraits presents the role of the king within the temple, a role that is necessary to the temple's completeness and function and do not have to be large, they are not political or propagandistic statements. Similarly, the Balance portraits are not important in themselves to the viewer; it is the message of imperial liberality of kingship that is intended. The relief portraits are an iconographical representation of

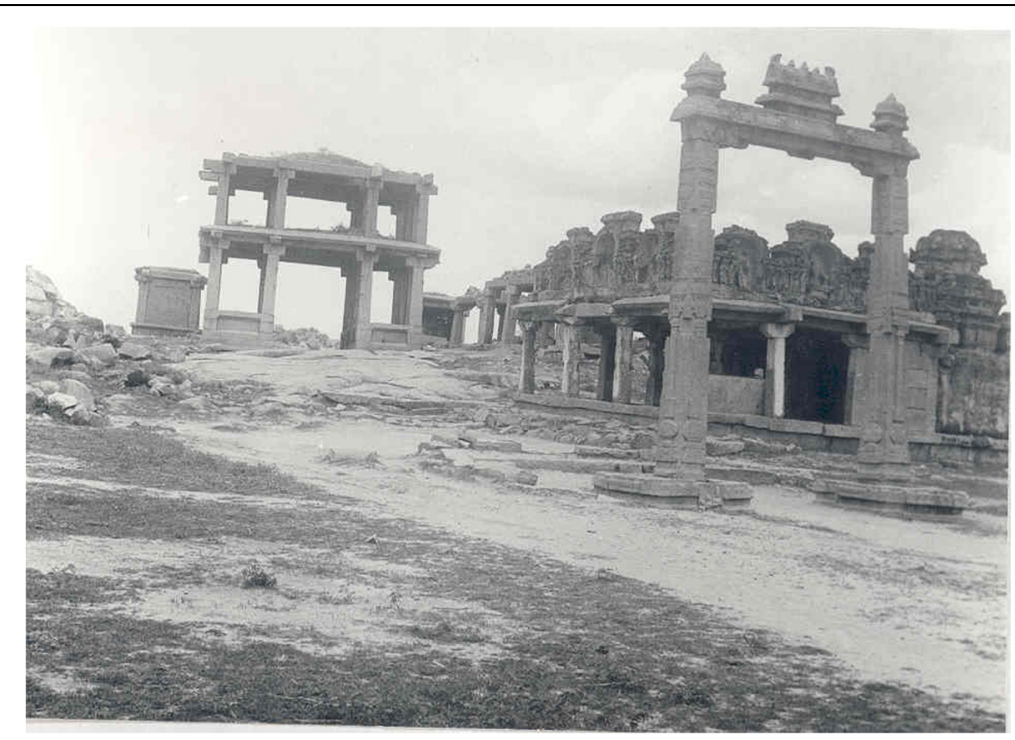

Fig. 3 The king's Balance in Hampi 
the view of religious authority towards kingship, the Balance portrait is the king's conception about his concept of protection, dharma and dāna.

On an examination of Vijayanagara inscriptions, it is found that among the numerous gifts, such as tulādāna, mahāpuruśdāna, suvarnamerudāna, aśvadāna, gajādāna, bhudāna, kannikādāna mentioned in the inscriptions, two most frequent ones cited in the inscriptions are the tuläpuruśdāna, when the king was weighed against gold and hiranyagarbhadāna the gifting of gold in the form of a golden embryo. The tuläpuruśadāna was performed by Krisnadeva Raya, and later by Acyuta Raya and Deva Raya. ${ }^{36}$ In addition, Vira Narasingaraya is said to have performed dānas, such as the tulādāna, mahāpuruśdāna, suvaranamerudāna, aśvadāna, gajādāna, godāna, bhudāna, kannikādāna and brahmapratiśthadāna. In fact, before abducting the throne, he is said to have performed ten dānas, sixteen mahädānas, as well as the suvarnatula, weighing oneself against gold, and mauktikatula, weighing oneself against pearls. Even as late as during the time of Venkata III, learned brähmaṇas were anointed or abundantly provided with gold by Venkata. ${ }^{37}$

In the sacred Puraṇas, sixteen mahādānas have been stated, including the tuläpuruśadāna, hiranyagarbhadāna, brahmāndadāna, kalpavrkśdāna, gosahasradāna, hiranyakāmadhenudāna, hiranyaśvadāna, hiranyasvarathadāna, hemahastirathadāna, dharādāna, viśvacakradāna, kalpalatādāna, saptasaāgarakadāna, ratnadhenudāna and mahābhutaghatadāna. ${ }^{38}$ Although the Agni Puraṇa (2001) states that there are sixteen great gifts, according to the Bhägavata Purana (1950), there are only ten, these being the kälapuruśdāna, saptsaāgaradāna, hahabhutaghatadāna, arghyapradāndāna, ātmapratikrtidāna, suvarnaśvadāna, suvarnaśvarathadāna, viśvacakradāna, krśnaajinadāna, aimagajarathadāna, krśnaajinadāna, āpakadāna. However, among them, the tuläpuruśadāna, and the hiranyagarbhadāna (meaning birth from a golden egg) were said to be of great significance for the Hindu kings "to establish or renew their universal imperial sovereignty". The tuläpuruśadāna which was considered to be the greatest gift, consisted of giving gold, jewels and other valuables equal to weight of a man, in this case to that weight of a king. Metaphorically, the wealth represented the vital breaths of a being and on the scale, and the riches and the donor were supposed to counterbalance and the gold to be given away. In the Bhägavata Purana Krisna is said to have described the ritual, the decorations and the pavilion to be constructed for the performance of the tuläpuruśadāna. What is significant is the utterance by the host, while consecrating the balance: "Oh balance, you are the might of the gods. You are the witness of the world. You are the mother. Visnu has created you. You stay between truth and falsehood. You also stay between the merit and demerit. You are the measure of all living beings. While weighing, you are requested to uplift me from this worldly course of life. The Supreme Being stays in you. Oh Govinda (i. e Tuläpuruśa) you are named Tulāpuruśa. So you are requested to uplift us from this world course of life." The Purana continues to mention that the host should climb into the balance with a sword, amour and a shield with him, wearing all the ornaments. With a golden Yama and a golden sun, a fight- fist, looking at Hari, he should ascend the pan of the balance, and gold should be placed in the other pan. Then he should utter, "Oh goddess Tula, you are produced by Brahma. You are the eternal witness of living beings. You have lifted the world containing the movable and the immovable. You stay in all living beings. I bow down to you." ${ }^{39}$ Such a ritual performed by someone holding a sword and armor and 
shield reveals that it was possible only for kings to perform the dāna. It had divine connotations, and was linked to Visnu and Agni, as gold is said to be the first offspring of fire, or Agni. ${ }^{40}$

\section{Conclusion}

The mahädānas with their spiritual and protective benefits were apparently an altruistic act and had immense dharmic and ideological values; non-performance of this religious ritual was a violation of dharma. However gifting had practical social implications for the maintenance of power between the religious and royal powers. Dharma rooted in the king's mind and the collective mentality of Hindu society, was used by royalty to yield indirect power over institutions. Royal beneficence entailed support for a broad range of architectural projects to fulfill the kings' dharmic obligations which included building tanks, wells and roads, support of monasteries and temples, all of which had architectural expressions. The ideology of 'dharmic mahādāna' was an aid in the king's assertion of universal imperial status, at a time when internal peace was important, and external troubles particularly by the Moslem Bahmani kingdom was a perpetual threat.

In addition, the Vijayanagar economy of temple urbanism depended on mahädānas that had increased tremendously, including both one time donations as well as annual gifts. ${ }^{41}$ The king granted large land grants to temples on every important occasion; he donated tax free lands and sometimes assigned them certain taxes that were payable to the court. In addition, nobles and merchants made gifts of villages, devadāna with its lands to the temple, and the donor renounced all rights including that of levying taxes. ${ }^{42}$ Regarding the economic value of royal gifting, it is quite certain that it was of substantial benefit for the economic sustenance of the temple, but the extent of economic dependence upon royal land and money endowments is difficult to understand in the absence of detailed records.

The large gifts to brähmanas had political and social motives. It was a means to sustain the class, accept their superior status, and once again maintain the caste system. Gifting sustained the caste which supported kingly values and meant the recognition of the brähmana who was the womb of kingly power. ${ }^{43}$ In exchange, the brähmana who came near the cultural concept of god, upheld royalty, accorded political legitimization especially at the time of coronations, bestowed honors, titles, and support to the king. Apart from the role of royal gifting being a mode of achieving legitimacy, it placed the brähmaṇa in a network of relationships and social control with the temple and king, all of whom had a community of interest which was conducive to the temple and brought them close in an active transactional relationship. The Vijayanagar kings were identified with the images of a protector, provider and largess and inscriptions clearly proclaim their beneficence and performance of gift ceremonies. This concept of the king as the most generous, who tried to bestow the good things in life to the people, is very clearly revealed in the contemporary historical text, Madhura Vijaya in which king Bukkaraya advises the prince to keep the people happy and to give gifts, as the people were the wealth of the nation. ${ }^{44}$ To the public, the king was an administrative hero and an embodiment of social generosity. It may be stated that gifting was a means of obtaining status but more importantly, it promoted social solidarity. He was also the royal protector of righteousness in the material world and as a protector, he was divine 
in the eyes of the people. Royal patronage of temples were gift giving acts, and were dharmic acts of kingship similar to the building of tanks and other civic structures by the king for the public good

Thus for the first time in South Indian history, a permanent stone structure for royal gifting was built which meant the institutionalization of the practice of royal liberality and that gifting was an essential aspect of medieval South Indian kingship. Although the balance portraits are small, the symmetrical structure of the Balance was a powerful symbol of the generosity of the king. In addition, the structure, located near the Vitthala temple and on the important road between the palace area and the temple cities or puras acted as a visual reminder of the generosity and largess of the kings. Necessitated by the changing political ideology, religion and societal changes, there was a transformation in the character and pattern of royal gifting which was substantiated by gift giving imagery. The king visually reaffirmed his superiority and autonomy as the pre-eminent person in the kingdom, subject to no one, ruler of all, as one who enjoyed the exclusive right to give gifts. Royal gifting was an act of devotion and Hindu dharmic ideology but also colored with an awareness of its material and symbolic value. It sustained the temple which was a citadel of economic power and an instrument of authority. Ostentatious gifts increased political stability and social order that affirmed the ethics of obligation and reciprocity and enhanced the sanctity of Vijayanagar kingship. The visual representation of dāna can throw a substantial light on liberal aspects of kingship in the context of historical evidences to illustrate in new ways, its close linkage with diverse institutions and patterns of shared relations centered around magnanimous architecture and visual imagery.

\section{Endnotes}

${ }^{1}$ Dallapiccola, A.L and S.Z. Lallemant, eds., (1985). Vijayanagara- City and Empire. Vol. 2.

${ }^{2}$ Sewell (1983) (Reprint) A Forgotten Empire: (Vijayanagar): A Contribution to the History of India.

${ }^{3}$ Heim, Maria (2004). Theories of the Gift in South Asia: Hindu, Buddhist, and Jain Reflections on Dāna: 5.

${ }^{4}$ Heitzman, James (1997). Gifts of Power: Lordship in an Early Indian state:145 ff.

${ }^{5}$ Marcel, Mauss. 1966. The Gift: Forms and Functions of Exchange in Archaic Societies.1966.

${ }^{6}$ Eck, Diana L (2013). The Religious Gift: Hindu, Buddhist and Jain Perspectives on Dāna. Social Research: An International Quarterly, 80.2: 359-379

${ }^{7}$ Rgveda V. I. 125.5 Rgveda Samhita (1849-74). Ed. F. Max Muller. 6 vols. Tr. Geldner 1951-57.Viśńndharmottara Puraṇa 3.300.1-2 Viśnudharmottara Puraṇa. 1912. Manusmriti 4.227 The Laws of Manu. 1967 (reprint of 1886 ed). Tr. Georg Bühler.

${ }^{8}$ Viśṇusmriti 92. Viśnusmriti. Venkateswara Press. Manusmriti 11.76

${ }^{9}$ Brahmānda Puraṇa 7.161. Brahmānda Puraṇa (1973). Ed. J. L. Shastri: 6. Bhāgavata Puraṇa III. 12.41 Bhägavata Puraṇa. 1950. Ed. Narayana Rama Acharya.

${ }^{10}$ Matsya Purana 274.11-12. Heroes such as Vasudeava, Ambarisa, Bhargava, Arjuna, Rama, Bharata are said to have made mahādānas. Matsya MahaPuraṇa (2007). Ed k. L. Joshi. 2 vols.

${ }^{11}$ Dirks, Nicholas (1987). The Hollow Crown, Ethnohistory of an Indian Kingdom: 28 
${ }^{12}$ Inden, Ronald. 1978. Ritual Authority and Cyclical Time in Hindu Kingship. In Kingship and Authority in South Asia. Ed., J. F. Richards: 28-73.

${ }^{13}$ Kane, P,V (1930-53). 2nd Ed. 1973. History of Dharmasastra: Ancient and Medieval, Religious and Civil Law, 5 Vols.

${ }^{14}$ Appadurai, Arjun and Carol Appadurai Breckenridge (1980). The South Indian Temple: Authority, Honour and Redistribution. Contributions to Indian Sociology: 10. 2: 187-211

${ }^{15}$ Rao, Nalini (2010). Royal Imagery and Networks of Power at Vijayanagara: A Study of Kingship in South India: 71

${ }^{16}$ Heitzman, James. 1997, op.cit.: 145

${ }^{17}$ Nicholas Dirks. 1987, op. cit. 37

${ }^{18}$ John M. Fritz, George Michell and M.S. Nagaraja Rao (1984). Where Kings and Gods Meet: The Royal Centre at Vijayanagara, India.

${ }^{19}$ Fritz, J.M (1985). Features and Layout of Vijayanagara: The Royal Centre. In Vijayanagara: City and Empire, ed. A. L. Dallapiccola and S.Z. Lallemant. Vol. 1: 240-256

${ }^{20}$ John Dowson, John (1867). (Reprint 1969). Ed. The History of India as told by its own Historians. The Muhammedan Period. 8 Vols. For Account of Abd-er-Razaaq, Vol. 4,1872: 107; Robert Sewell: 255

${ }^{21}$ Heitzman, op.cit.:108

${ }^{22}$ South Indian Inscriptions (1903-04). No 227

${ }^{23}$ The temple invested the surplus back into its own local region.

${ }^{24}$ Appadurai, Arjun (1981). Worship and Conflict under Colonial Rule: A South Indian Case: 84

${ }^{25}$ Derret, J. D. M (1968). Religion Law and the State in India: 486

${ }^{26}$ South Indian Inscriptions. II. 4: no. 259. Epigraphia Indica. 1: 361-371

${ }^{27}$ Rao, Nalini (1992). Royal Portraits at Vijayanagara: Identification and Meaning. In New Trends in Indian Art and Archaeology, Vol 2.,eds., B. U. Nayak and N.C. Ghosh: 349-368.

${ }^{28}$ Acyuta Raya is said to have had Raghunatha, the poet, bathed in gold and precious stones, kanakaratnabhisekham, unction with gold and pearls, after he wrote the poem Parijatapaharana in six hours as mentioned in the Sahityaratnakara by Yoganarayana Dikshita. Aiyangar, Krishnaswami (1919). Reprint 1986. Sources of Vijayanagara History: 270.

${ }^{29}$ South Indian Inscriptions. 9. pt. 2: nos. 557, 558.

${ }^{30}$ The purpose of the gift is enumerated by Hemadri in the dasakhanda of his Chaturvarga Chintamani. Satyanathan, Ruth Sheilavardhini. 1977. Achyuta Raya. Unpublished Ph. D. dissertation. Karnatak University. Dharwar. 61-62.

${ }^{31}$ Confirmed by the Achyutarayabhyudayam. Sathyanathan, op.cit. In the inscription of Ankavalli Sorab Taluk, dated c.1529 A.C.E., the donor made a grant in order that Acyutaraya might be established in the empire.N.Venkataramanayya, N. 1936. Studies in the Third Dynasty of Vijayanagara: 14.

${ }^{32}$ Aiyangar, K. Op. cit. 1986: 161.

${ }^{33}$ In the inscription of Ankavalli Sorab Taluk, dated 1529, the donor made a grant in order that Acyutaraya might be established in the empire. Ramanayya, N. Venkata (1935). Studies In The History Of The Third Dynasty Of Vijayanagara. Madras University. Historical Series, No. 11: 14.

${ }^{34}$ Sastry, Sri Sadhu Subrahmanya (1981). Tirumalai: Tirupati Sri Venkatesvara Tirupati: Tirupati Devasthanams. 211. 
${ }^{35}$ Rao, Nalini. 2010.Op. cit.

${ }^{36}$ Epigraphia Carnatica (1919). nos. 511, 543, 546.

${ }^{37}$ Epigraphia Indica Vol 1 (1882): 236 Vol 3 (1894): 258.

${ }^{38}$ Agni Purana. 210. 1-4 cf. Agni Purana. Ed. K.L. Joshi. 2001. They are also described in the Matsya Purana chapters 275 - 289 and the Linga Purna chapters 2, 29, 33, 35, 38.

${ }^{39}$ Bhāgavata Purana. Uttaraparva 175. 81-82; Also found in the Matsya. Purana. 274. 59 cd-64.Bhägavata Puraṇa. Ed. Narayana Rama Acharya. 1950.

${ }^{40}$ Bhagavat Purana, Uttaraparva 176.3. Acharya, Kala (1993). Puranic Concept of Dāna: 182.

${ }^{41}$ In an inscription of 1405 , the opening genealogy includes the statement that his (Bukkaraja's) son is King Harihara, who equals sutraman (Indra) in power and who, being devoted to the performance of the sixteen great gifts, has destroyed the sins of the Kali age. Epigraphia Indica. 3: 224-230.

${ }^{42}$ Villages of Devasamudra were no longer paying taxes to the temple as prescribed in the inscription of c.1557 A. C.E.

${ }^{43}$ Dumont, Louis (1970). The Conception of Kingship in Ancient India. In Religion,

Politics and History in India: 62-88.

${ }^{44}$ Shanbhag (1964). Gangadeviya Madhura Vijaya: 5 ff.

Competing interests

I declare that I have no competing interests.

Received: 8 December 2015 Accepted: 21 January 2016

Published online: 19 July 2016

References

\section{Primary Sources}

Agni Purana. Ed. K.L. Joshi. 2001. Delhi: Parimal Publications.

Bhāgavata Purana. Ed. Narayana Rama Acharya. 1950. Bombay: Nirnaya Sagar press.

Brahmanda Purana. Ed. J. L. Shasri. 1973. Delhi: Motilal Banarsidass.

Epigraphia Carnatica. 1919: nos. 511, 543, 546. Ed. Lewis Rice and others. Madras 1886.

Epigraphia Indica Vol 1 (1882) and Vol 3 (1894).

Matsya Mahapurana. Ed K. L. Joshi. 2 vols. 2007.Delhi: Parimal publications.

Rgveda V. I. 125.5 Rgveda Samhita. 1849-74 Ed. F. Max Muller. 6 vols. Tr. Geldner 1951-57

South Indian Inscriptions. No 227. 1903-04 Ed. D.C. Sircar. Govt. Press. Madras: Archaeological Survey of India.

Viśnudharmottara Purana. 1912. Bombay: Venkatesvara Press

\section{Secondary Sources}

Acharya, Kala. 1993. Puranic Concept of Dāna. Delhi: Nag Publishers.

Aiyangar, Krishnaswami. Ed. 1919, 1986. Sources of Vijayanagar History. Madras: University of Madras. Reprint 1986. Delhi: Gian Publishing House.

Appadurai, Arjun. 1981. Worship and Conflict under Colonial Rule: A South Indian Case. Cambridge: Cambridge University Press.

Appadurai, Arjun and Carol Appadurai Breckenridge. 1980. The South Indian Temple: Authority, Honour and Redistribution. Contributions to Indian Sociology. 10. 2: 187-211

Dallapiccola, A.L., and S.Z. Lallemant (eds.). 1985. Vijayanagara- City and Empire. Vol. 2. Stuttgart: Franz Steiner Verlag Wiesbaden GMBH

Derret, J.D.M. 1968. Religion Law and the State in India. London: Faber and Faber.

Dirks, Nichola. 1987. The Hollow Crown : Ethnohistory of an Indian Kingdom. Cambridge: Cambridge University Press.

Dowson, John. 1867. Reprint 1969. The History of India as told by its own Historians. The Muhammedan Period. Edited from the posthumous papers of the late Sir Elliot by John Dowson. 8 Vols. London: Trubner. 1867. Reprint. 1969. Allahabad: Kitab Mahal.

Dumont, Louis 1970. The Conception of Kingship in Ancient India. In Religion, Politics and History in India: 62-88.

Eck, Diana L. 2013. The Religious Gift: Hindu, Buddhist and Jain Perspectives on Dāna. Social Research: An International Quarterly, 80.2: 359-379

Fritz, J.M. 1985. Features and Layout of Vijayanagara: The Royal Centre. In Vijayanagara: City and Empire. Ed. A. L. Dallapiccola and S.Z. Lallemant. Vol. 1., 240-256.

Fritz, John M., George Michell, and M.S. Nagaraja Rao. 1984. Where Kings and Gods Meet: The Royal Centre at Vijayanagara, India. Tucson: University of Arizona Press.

Heim, Maria. 2004. Theories of the Gift in South Asia: Hindu, Buddhist, and Jain Reflections on Dāna. NY: Routledge. Heitzman, James. 1997. Gifts of Power: Lordship in an Early Indian state. Oxford: Oxford University Press. 
Inden, Ronald. 1978. Ritual Authority and Cyclical Time in Hindu Kingship. In Kingship and Authority in South Asia, ed. J. F. Richards, 28-73. Madison: University of Wisconsin.

Kane, P,V. 1930-53. 2nd Ed. 1973. History of Dharmaśästra: Ancient and Medieval, Religious and Civil Law, 5 Vols Mauss, Marcel. 1966. The Gift: Forms and Functions of Exchange in Archaic Societies. Cohen and West Ltd: Tr. Ian Cunnison. London.

Ramanayya, N. Venkata: Studies In The History Of The Third Dynasty Of Vijayanagara, 1935. Madras University. Historical Series, No. 11: 14

Rao, Nalini. 1992. Royal Portraits at Vijayanagara: Identification and Meaning. In New Trends in Indian Art and Archaeology. Vol 2, ed. B.U. Nayak and N.C. Ghosh, 349-368. New Delhi: Aditya Prakashan.

Rao, Nalini. 2010. Royal Imagery and Networks of Power at Vijayanagara: A Study of Kingship in South India. Delhi: Originals.

Sastry, Sri Sadhu Subrahmanya. 1981. Tirumalai: Tirupati Sri Venkatesvara Tirupati: Tirupati Devasthanams.

Sewell. 1900. Reprint 1983. A Forgotten Empire: (Vijayanagar): A Contribution to the History of India. London: Swan

Sonnenschein and Co. 1900. Reprint, 1983. New Delhi: Asian Educational Services

Shanbhag, 1964. Gangadeviya Madhura Vijaya, Dharwar: Viswavidyalaya.

\section{Submit your manuscript to a SpringerOpen ${ }^{\circ}$} journal and benefit from:

- Convenient online submission

- Rigorous peer review

- Immediate publication on acceptance

- Open access: articles freely available online

- High visibility within the field

Retaining the copyright to your article

Submit your next manuscript at springeropen.com 